\title{
Does Religious Counselling on Abortion Comply with Sweden's 'Women-Friendly' Abortion Policies? A Qualitative Exploration Among Religious Counsellors
}

\author{
Jonna Arousell ${ }^{1}$ D $\cdot$ Aje Carlbom ${ }^{2} \cdot$ Sara Johnsdotter $^{2} \cdot$ Birgitta Essén $^{1}$
}

Published online: 30 May 2019

(c) The Author(s) 2019

\begin{abstract}
The abortion discourse in Sweden is marked by historically liberal ideals about women's inviolable right to make autonomous reproductive decisions. However, to respond to the increase in cultural and religious pluralism building up over several decades, religious organizations have been given opportunities to provide so-called spiritual care in affiliation with Swedish hospitals since the 1980s. In this study we asked: in what ways do religious counsellors, affiliated with Swedish hospitals, construct their ideas on abortion, and how well do their ideas comply with Sweden's 'women-friendly' abortion policies? Through interviews with Protestant, Catholic, Muslim, and Buddhist religious counsellors, we wanted to empirically test the presumption underlying the decisions to grant space to religious actors in Swedish healthcare, i.e., that religious counselling serves to complement existing services. We found that it cannot be expected that religious advice on abortion will always comply with Swedish abortion law and with the women-friendly abortion policy that the Swedish state seeks to impose. When policy-makers open up possibilities for diverse norms on abortion to manifest in close affiliation with healthcare institutions, they must be aware that some religious counsellors argue that only God-and not the woman herself_-can decide whether a woman can terminate a pregnancy. We argue that the findings in this study speaks to what researchers have referred to as the "diversity-equality paradox", which highlights the tension between the promotion of religious ideas on abortion on the one hand and the promotion of liberal ideas about women's reproductive freedom on the other.
\end{abstract}

Keywords Abortion · Women's rights $\cdot$ Religious counselling $\cdot$ Diversity promotion $\cdot$ The diversity-equality paradox $\cdot$ Healthcare $\cdot$ Sweden

Jonna Arousell

jonna.arousell@kbh.uu.se

1 Department of Women's and Children's Health (IMCH), Uppsala University, 75185 Uppsala, Sweden

2 Faculty of Health and Society, Malmö University, 20506 Malmö, Sweden 


\section{Introduction}

The abortion discourse in Sweden is marked by historically liberal ideals about women's inviolable right to make autonomous decisions about their own reproduction (Elgán 1994; SOU 2005:90). Women in Sweden can legally have an abortion until the end of pregnancy week 18 (Abortion Act, §1). No special permission is needed and the woman is not obliged to inform anyone about her reasons for wishing to terminate the pregnancy (Government Bill 1974:70). The values associated with abortion in Sweden, accordingly, often contribute to this country being considered one of the most 'women-friendly' in the world (Liljeström 1974). At the same time, however, Swedish policies reveal a relatively extensive desire that public welfare institutions should help to promote and protect society's cultural and religious diversity (Borevi 2014; Government Bill 1997/98:16; Government Bill 1975:26). This ambition should be viewed in light that, over the past few decades, many people have migrated to Sweden from non-European countries, which has made society increasingly diverse. One of the government's ambitions when multiculturalist policies emerged in Sweden in the 1970s was that immigrants should "be given the possibility to choose the extent to which they want to adopt a Swedish cultural identity or maintain and develop the original identity" (Government Bill 1975:26, p. 1). In order to realize this ambition, Swedish policy-makers have for many years encouraged a close cooperation between public welfare institutions and various faith communities. As one example, which has relevance for Swedish reproductive healthcare, the Swedish Agency for Support for Faith Communities (SST) regularly allocates state funding to religious organizations to allow them to provide religious counselling services (in Swedish: Andlig vård) to patients in Swedish hospitals (SOU 2018:18).

The underlying assumption for the decision to involve faith communities in the provision of care in Sweden appears to be that such services complement the existing ones (SOU 2018:18; SST 2017). However, the suggestion that religious counsellors in Sweden would always give women abortion advice that complies with Sweden's 'women-friendly' abortion politics seems to be an implicit, speculative one. To date, no research studies exist about the extent to which faith communities contribute to nurturing ideas about women's rights and gender equality in Swedish society (SOU 2018:18). In this study, we wanted to empirically test the presumption that religious counselling serves to complement, in this case, the Swedish abortion law and the 'women-friendly' approach to abortion, at all times. We asked: In what ways would religious counsellors in Sweden advise a woman who is considering an abortion, or who has already had one? How do they view their role as 'religious advisers' affiliated with Swedish healthcare? And how do their views on abortion consultation comply with the women's rights perspective in Swedish abortion law and policies?

The study is based on interviews with religious counsellors drawn from four faith communities in Sweden, all of which are affiliated with public healthcare institutions. We expect that the exploration will add insights to the field of study that is concerned with how religious ideas intersect with various health-related 
questions. In a broader sense, the question is relevant with regard to how a diversity of lifestyle ideas compare to Swedish healthcare policies on equality.

\section{Spiritual Counselling in Healthcare: A Background}

Since the number of immigrants settling down in Sweden began to increase during the 1960s and 1970s, Sweden's take on integration has slowly shifted from assimilation policies to policies based on multiculturalist ideals (Borevi 2014; Wickström 2015). In Swedish public discourse today, there is a strong political support for multiculturalism in the sense of recognizing "Swedish society as inherently culturally diverse in character" (Borevi 2013, p. 152). Although the Swedish integration policies do not grant immigrants any formal rights to be excepted from national laws and regulations (Borevi 2013), there is a generally high level of support for interventions that help people to be part of Swedish society without "needing to comprise one's own cultural and ethnical identity" (Government Bill 1997/98:16, p. 23).

The multiculturalist ambition of facilitating cultural inclusion and accommodation is, for instance, illustrated in the decision to create a close affiliation between religious counsellors and Swedish healthcare institutions. While the Swedish Church has provided spiritual care as an integral part of Swedish medical healthcare since the Protestant Reformation of 1527, it was only in the 1980s that the state decided that additional faith communities could apply for financial support to offer so-called 'hospital services' (SOU 2018:18). The broadening of spiritual care to include faith communities other than the Swedish Church was considered to be an important step towards promoting a greater degree of inclusiveness and non-discrimination (SST 2017). The preparatory documents for allocating state support for religious counselling indicate that the services "are funded in the holistic view of healthcare that county councils/regions establish in their basic values, guidelines, etc., and which means that both physical, psychological, social, and spiritual or existential needs should be viewed as important components of good care" (SST 2017, p. 11). People's religion-in this holistic version of healthcare provision-is believed to supply individuals with: "Things that give life meaning, it [religion] can contribute with a sense of security, a sense of coherence, and to give people hope, for example" (personal communication, SST, 2016-10-13). The argument is that the more integral the role is that faith communities have in the delivery of welfare services, the easier it will be to "increase understanding and respect for different orientations in beliefs and thereby neutralize the polarization in society" (Government Bill 2015/16:1, p. 37).

The scientific evidence regarding the content and effects of religious counselling within healthcare institutions globally is, nevertheless, sporadic. While many have argued that religious leaders can help to encourage healthy behaviours among devout patients (Padela et al. 2011; AlRawi et al. 2012; Underwood et al. 2013; Moberg and Ståle 2014), critics claim that it cannot be taken for granted that religious leaders would always agree with policy-makers about the best options for the prevention of disease or medical treatment. Ruijs and colleagues, for instance, found that the views on vaccination among religious leaders in their study varied "from 
full acceptance to clear refusal" (Ruijs et al. 2013, p. 1). Existing evidence shows that, while some religious leaders' ideas regarding a specific query can be compatible with official health policies in one country, other advice may be incompatible with the state's public health interests (Underwood et al. 2013). In Sweden, several studies have pointed out that, in the Swedish discourse on multiculturalism, it is often taken for granted that 'cultural diversity' is automatically enriching (Carlbom 2003; Wickström 2015). Thereby, there is a risk that authorities and policy-makers are open to the acceptance of values that are in opposition to laws, regulations and norms in society without critical reflection (Ouis et al. 2013).

\section{Methods}

\section{Study Setting}

Religious counsellors from the Christian Hospital Church (Sjukhuskyrkan), counsellors from the Swedish Buddhist Cooperation Council (Sveriges Buddhistiska Samarbetsråd, $S B S$ ), and counsellors from the Muslim organizations that are represented in the Islamic Cooperation Council (Islamiska Samarbetsrådet, ISR) are affiliated with Swedish healthcare today. Counsellors from these three faith associations are available in almost all of the county councils in Sweden. The Hospital Church can best be described as a cooperation of several Christian churches that provide spiritual care in Swedish hospitals. ${ }^{1}$ Within the Hospital Church, the Evangelic-Lutheran Swedish Church (Svenska kyrkan) is the church with the most counsellors available in healthcare institutions across Sweden. The Catholic Church is also a part of the Hospital Church, but is smaller with regard to the number of counsellors available in healthcare.

Sometimes the religious counsellors are physically located in offices within the hospitals, whereas some counsellors are called into the hospitals only when someone asks them to be present. Contact information is available in information brochures and online, and often, healthcare staff can give guidance on how to get in touch with the counsellors. When a patient, family member or the healthcare staffs want to talk to a counsellor from the Hospital Church, they can contact a counsellor who has an office in that hospital. This person can in turn help to get in touch with a counsellor from a specific church, if needed. When a Muslim patient or member of hospital staff wants to contact a Muslim counsellor, they can either contact one of the three existing hospital Imams (who are employed at a full-time equivalent of at least $50 \%$ and who have offices in three different hospitals), or, alternatively, a so-called hospital coordinator (an Imam or a Muslim layman, usually employed at $25 \%$ ). If the hospital Imam or the hospital coordinator cannot provide the patient with satisfactory spiritual support, they have the possibility to refer the patient to a religiously educated person drawn from the hospital's 'volunteer list'. Buddhists,

\footnotetext{
1 The Hospital Church comprises several Christian Orthodox churches, Free Church communities, the Catholic Church, and the Evangelic-Lutheran Swedish Church.
} 
on the other hand, can contact a Buddhist hospital coordinator (and also a Buddhist layman), and can be referred to a religiously trained Buddhist on the 'volunteer list'. The Buddhists on the volunteer list are usually handpicked according to their professional competence. They include, for instance, healthcare staff or professional counsellors.

Abortion counselling and abortion care in Sweden is, in turn, provided in abortion clinics in hospitals or in private gynaecological clinics. The National Board of Health and Welfare must approve private clinics that wish to provide abortion care (Abortion Act, §5). Regardless of where the abortion is performed, the woman should be offered support and/or counselling with a professional counsellor, such as a psychologist or a social worker (kurator), prior to the abortion (Abortion Act, §2). The woman should also be offered support after the abortion procedure (Abortion Act, §8). Religious counsellors are not officially authorized to provide such consultations, and women are not required to talk to a religious counsellor (or anyone else) with regard to the abortion decision or procedure. The bearing principle in Swedish abortion care is that the woman is the sole decision-maker regarding a termination of pregnancy (Abortion Act, $§ 1$ ). The role of religious counsellors in Swedish abortion care is thus the same as their role in healthcare in general: they are available in case a patient, family member, or member of the healthcare staff wishes to consult them.

\section{Informants and Procedure}

Qualitative interviews took place between 2016 and 2017, and were conducted by the first author (JA). Four Muslim counsellors, two Buddhist counsellors, one Catholic counsellor, and one counsellor from the Swedish Church were included in the study. All informants were affiliated with Swedish healthcare institutions: some had offices in the hospitals, whereas others were contacted and called in by other counsellors, patients, family-members, or healthcare professionals as and when anyone needed their help. Some of the informants were religiously trained persons within their respective faith organization, whereas others were laymen, i.e., persons with a great interest in religious questions but who had not obtained any formal religious education or training. None of the informants had, to our knowledge, any medical education.

The first author contacted most of the counsellors personally by phone or by email, as listed on the official websites of the respective faith organizations, and invited them to participate in the study. A few counsellors were invited to participate in the study after that the first author had received recommendations and contact information from some of the informants who had already been interviewed. Four interviews were conducted face-to-face in a location of the interviewees' own choice. The remaining four interviews were conducted by telephone. The interviews lasted between $45 \mathrm{~min}$ and $1.5 \mathrm{~h}$ and were conducted in Swedish.

During the interviews, informants were asked to describe their stance on abortion and the religious principles underpinning their position, to describe their role and perceived obligation as religious counsellors affiliated with Swedish healthcare, and 
to reflect upon how they-hypothetically or based on previous experiences-would counsel a woman who is considering an abortion, or who has already had one. All interviews were audio recorded and most interviews were transcribed in full. The collection of data ended when theoretical saturation had been reached.

\section{Selection of Informants}

The rationale for including more Muslim counsellors than counsellors from the other faith communities in the study was that the study is part of a larger project that focuses on the provision of reproductive healthcare in Swedish multicultural society-with specific focus on discourses on Islam and Muslim patients. We began by interviewing Muslim counsellors, but, as the study proceeded, we sensed that the interviews gave only scarce information about the broader understandings and implications of religious counselling in Swedish hospitals. The inclusion of counsellors from other faith communities was, accordingly, an attempt to provide a more qualified answer to how religious counselling in Swedish healthcare-as a social phenomenon-could be theorized and hence better understood.

The religious counsellor from the Swedish Church was included in the study because the Swedish Church is the largest Christian Church in Sweden, and also the Church that has most counsellors available in Swedish healthcare institutions. Counsellors from the Catholic Church and the Buddhist cooperation council were included because these faith communities are the most well-established ones in Swedish healthcare today, apart from the Swedish Church and the Muslim communities (SST 2019). By including religious counsellors from a diversity of faith affiliations, we expect that the study will inform on-going discussions about how the Swedish egalitarian welfare state responds to society's increased cultural and religious pluralism (Bendixsen et al. 2018).

\section{Ethics}

Prior to the interviews, the interviewees were informed about the study and its purpose. Verbal consent was obtained. To ensure their confidentiality, we hereafter refer to all informants as 'counsellors', regardless of whether they were laymen or were religiously trained within their community. Pseudonyms have been used throughout the article. The study was approved by the Regional Ethics Board in Uppsala, Sweden (Dnr. 2013/346).

\section{Analysis}

The first part of the analysis was oriented towards achieving an understanding of the phenomena of religious abortion counselling from the informants' own points of view. This was accomplished through repeated listening to the audio recordings, and reading of the transcripts. We approached the material as representing discursive statements, and we focused the analysis towards how informants positioned themselves in relation to various representations of abortion. The main goal of this part 
of the analysis was, as described by Stebbins, to inductively derive some tentative generalizations and recurrent patterns about the questions being studied (Stebbins 2001). The second part of the analysis sought to weave these patterns together to obtain a broader idea about how the phenomena of 'religious abortion counselling' can be understood. This part of the analysis can best be described as a process of abstraction (Lincoln and Guba 1985): instead of just describing informants' narratives, the analysis intended to deepen the awareness of what religious abortion counselling meant in relation to official laws and public health agendas on abortion in Sweden.

\section{Methodological Demarcations}

It should be stressed that the study does not aim at providing an exhaustive review of the content of religious counselling on abortion among all religious counsellors, or all faith communities, that are active in Sweden. For instance, no counsellors from any of the Orthodox Churches or any of the Free Churches within the Hospital Church were included in the study. We also acknowledge the difficulties in making general predictions about the kind of norms that counsellors will reflect, because they adhere to various religious schools of thought-both inter- and intrareligiously-that will lead them to draw different conclusions based on religious sources. The study was exploratory, in the sense of seeking to generate an initial understanding of what it might mean to provide religious counselling on abortion. Accordingly, our intentions have not been to make any empirical generalizations with regard to religious counselling in Swedish hospitals. Our ambition has instead been to generate what Polit and Beck (2010) have referred to as 'analytical generalizability', which encompasses researchers' attempts to provide an analysis that is deep and rich enough to provide new insights into a specific field of understanding (Thorne et al. 2009).

All of the faith communities with which the informants in this study are affiliated (as volunteers or employees) are qualified for receiving ear-marked state funding for providing spiritual counselling in hospitals. In this study, however, we have not aimed at providing any detailed exploration of the exact allocation of funding, for instance, to whom monies are allocated, what amounts, with what frequency, and for what precise purposes. To conduct such a careful mapping of resource allocation falls outside the scope of this article.

\section{Results}

\section{Drawing Boundaries for 'Correct' Religious Choices}

The aim of the religious counselling activities is, as most informants from the Muslim, Buddhist, and Catholic churches argued, to provide the advice-seeking person with what they described as being religiously correct ideas. Informants described how they had an obligation to provide advice in accordance with religious norms 
and rules; an obligation that appeared to be twofold. First, they have an obligation to provide the 'correct' advice to the person who seeks care. Abdel, a Muslim counsellor, said:

Because Muslims are usually very religious, and, at the end of the day, they want answers on their [religious] questions, and they will ensure that the answers are given through Islamic law.

Hasan, a counsellor from the Muslim Sunni community, argues in a similar way. He said that he supports the Swedish law and that Swedish law is the legislative document that differentiates right from wrong in Sweden. But, he continues, Sharia (i.e., Islamic law) is still valid for those who are aware of it, which means that his advice must be given so as to ensure that Muslim people can live the kind of religious life that they want:

This is how it is: [these recommendations are valid for] those who respect Islam and for those who live an Islamic life, and those who accept it. If you are not in this, what can I say, in this 'root', then it is possible to make whatever you want and however you want. If you understand what I mean, how it is with Sharia?

Second, the counsellors presented that they have an obligation to provide advice in accordance with religious norms that also seeks to safeguard their own status as religious subjects. Providing someone with the 'wrong' information, i.e., information that deviates from religious standards, was argued to jeopardize the counsellors' own divine obligation in relation to God. Father James from the Catholic Church said that it would be impossible for him, as a religious counsellor, to make exceptions to religious principles in order to make it, for instance, easier for a young woman to follow her wish to have an abortion:

No, no, no, no. [...] Everything is of course possible but, no, it would be wrong. And then $I$ would have to ask for forgiveness for this afterwards [laughs]. And it would be considered as particularly serious, especially for me [as a counsellor].

In the same way, it would be highly disadvantageous for a Buddhist monk to give advice that does not comply with religious teachings, as the Buddhist counsellor, Kristina, explained:

[It would generate] bad Karma if one were encouraging [a religiously discouraged action] and would say: "Yes, yes, it's nothing to care about, just do it". [...] So this is clearly not good for the monk. He must inform honestly about what the Law of Karma says.

Informants often described that they had no authority to adapt the religious advice that they provided in order to promote a better fit with healthcare policies or Swedish legislation. The advice must be given according to what the informants appreciated were adequate religious standards, and also so that it does not convey perspectives that are uncomfortable or inconvenient for the person who seeks advice. 
A divergent perspective was, however, brought forward by the counsellor, Thomas, from the Swedish Church. Many of the people who he offers counselling to do not necessarily ask for religious advice, but turn to him in order to obtain general existential counselling. Thomas speculated that people in Sweden today are less concerned about practical, religious life rules, but more concerned about existential queries:

It is very seldom about what [a person] should do to "behave correctly" in relation to his or her religious faith. The counselling takes on more of an existential character, and very little about how one should pray or how one should eat.

Given that the counselling is of an existential character rather than being guidance about how to live life 'correctly' according to Christian principles, Thomas described how it has happened, for example, that both atheists and Muslims have sought his support. Accordingly, he described the content of his religious counselling as being "stumbling close" to the counselling provided by psychologists and other behavioural-science therapists employed in Swedish healthcare institutions. The reason why people come to him, Thomas hypothesised, is that he is bound by secrecy and does not make any entries in medical records, which members of other professional groups are obliged to do. He described how he believes that people are sometimes more likely to talk freely if they know that nothing of what they say will become documented and, in the worst case, disclosed to anyone: "There's a comfort in knowing that what you say stay with me, it goes nowhere else".

\section{Constructions of 'Human Life'}

Many informants held the view of a 'sacred human life' in common. Most informants, except the counsellor from the Swedish Church, suggested that it is more important to protect the life of the unborn foetus than to ensure that women's inviolable right to decide whether to terminate a pregnancy is upheld. Likewise, Thomas, from the Swedish Church, was the only religious counsellor in our study who expressed his explicit support of the Swedish abortion law, contending that he finds that the time limit reflects a reasonable balance between women's rights versus the foetus' right to life. The counsellors from the Catholic Church, the Buddhist organizations, and the Muslim organizations presented diverse opinions about the time limits and the circumstances regulating when, if at all, a woman can have an abortion.

The Muslim counsellors gave some of the more liberal recommendations on abortion when compared to the Buddhist and Catholic counsellors. Hasan confirmed that the advice must be well anchored in Islamic doctrine: "Most Islamic scholars who interpret Sharia, meaning interpreting the Quran, conclude that 'after 120 days, no one can have an abortion'". The source used among Sunni Islamic jurists to determine the last day for the termination of pregnancy comes from a hadith (i.e., narratives from the Prophet Mohammed) that can be found in the hadith collections 
Sahih al-Bukhari and Sahih Muslim, which were narrated by Prophet Mohammad's companion, Abdallāh ibn Mas'ūd, Hasan explains. He read out loud:

According to Islam, and according to the Prophet, "the development of the foetus starts with one drop of semen that develops to a bulge throughout three periods, totally lasting for 120 days, where every period is 40 days". And then he explains: "In the end of the third period, the tradition says that God sends down an angel with the mission to write down the foetus' course of life, conditions in life, and happenings in life. First when these conditions are decided upon, [God will] blow life into the foetus". So this means that God blows life into the foetus after these 120 days, and then life is created. At that point, it is absolutely prohibited to have an abortion.

Yet, Hasan clarifies, an abortion can, according to Islamic law, only be performed until day 120 when "the mother's life is in danger or if the foetus is so severely ill that it will die after delivery anyway". If a woman who approached him lacked such valid reasons, he would always advise her not to have an abortion: "I would always advise that she should not do it. And if I had received a question from a woman in the fifth week [of pregnancy], I would still discourage her from having an abortion. I mean, in case she does not have a strong reason" (again, a "threat to the mother's life" and "severe malformations of the foetus" were referred to as strong and thus valid reasons for terminating a pregnancy).

The Catholic counsellor, Father James, explained that abortion is prohibited in all circumstances, even when the pregnancy is a result of rape or incest. The rationale for this is that, in Catholic belief, human life is thought of as being created at the moment of conception, and, as all life is considered sacred, it cannot be legitimately extinguished, he said. Father James retells a story from the Bible to support the perception that the foetus has been blessed with a soul long before it meets the outside world:

One thing that is mentioned in the Bible is when Maria, who had just become pregnant, visited her cousin Elisabeth [who was also pregnant], and greeted Elisabeth. And the unborn child, John the Baptist, kicked with joy inside his mother's womb. And it is said that the two women greeted each other and that the two unborn children greeted each other.

For Catholic believers, Father James explains, the principle of sacred human life in relation to abortion is an important aspect to consider, because most Catholics strongly believe that the unborn child is already a human being.

The two Buddhist counsellors who were interviewed revealed somewhat divergent views on abortion. Kristina was firm in her conclusion: abortion can never be religiously justified. If a woman has an abortion, it would violate the very fundament of the Buddhist faith, i.e., the belief that human life is created at the moment of conception and thereafter sacred. Indrajalin, on the other hand, exposed larger struggles in how to deal with this deeply rooted belief where a Buddhist woman in Sweden might face an unwanted pregnancy. The Buddhist group in which he is 
ordained defines itself through its liberal and women-friendly approach. This has an impact on their view of abortion, he continued:

I experience that the idea of women's rights to decide over their own bodies also is very important. This is at least [the idea] in the Buddhist community were I spend time. Like for me, personally, I cannot imagine a society where women were not given the possibility to choose. Where they would have to go to a backstreet somewhere in the underworld and get someone's help with a tin lid or something like that. That doesn't feel very appealing at all, I'm very happy we live in a country where the state offers the possibility for good healthcare.

At the same time, it would be impossible for him to tell an advice-seeking woman that it is unproblematic to have an abortion from a Buddhist perspective, he continues. Having an abortion is what Indrajalin refers to as an 'unskilful action'; i.e., a type of action that does not serve to promote the highest standard of well-being for oneself or other people. "What we [in the Buddhist community] mean, is that it doesn't actually matter how many weeks it [the foetus] is [...]. As soon as the egg is fertilized, life has begun". Thus, where a woman would consult him on the question, he would have to try to juggle between the two opposite positions:

If she consults me in my role as ordinated Buddhist, I assume that this is the information she wants to have. And then it is a matter of how I communicate this information [...]. I would like to express both perspectives at the same time. Like, "Yes, it is really important that you can choose but these are the reflections that Buddhism delivers about life and to take a life."

\section{Solutions, Sanctions and Possible Effects}

Depending on the advice-seeking woman's individual situation-whether she is married or unmarried, and whether she has only considered having an abortion or has already had one-most religious counsellors proposed various routes of action.

The Catholic, Muslim and Buddhist counsellors described how it should be ensured that the woman acts in accordance with religiously appropriate standards. They talked about their obligation to 'assist' women in making the right decision. Muslim women sometimes need their help, Abdel argued, because they may be too caught up in emotional struggles and therefore lack the ability to make rational decisions. He described how he believes that women may feel tempted to have an abortion because they are afraid of giving birth, or because they are in a bad financial situation. If he counsels a woman who has hesitations about whether to have an abortion, he considers it his responsibility to-always according to interpretations of sharia- "support people so that they can better see the whole picture. [Therefore,] I am all the time trying to convince the woman not to have an abortion".

The Catholic counsellor, Father James, also recalled several situations in which he used several strategies to compel women not to terminate the pregnancies. This was the case when, some years ago, he met two teenage women from his community 
who had become pregnant out of wedlock. One of the women wanted to keep the child, while the other woman was more hesitant:

Father James: I encouraged both [of] them to [keep the child]. They both came from very devout and practising Catholic families. I encouraged them to keep the babies and I tried to be very positive [...]

Researcher: So when you spoke to these girls, what sort of arguments did you, from a religious perspective, use to motivate them to keep the babies?

Father James: Yes, so from my perspective, it is in some way naturally given, it is self-evident [not to abort]. I remembered what Mother Theresa in Calcutta used to say. She used to congratulate girls being in that situation, to be very encouraging and [explain that] "we will give you all the help we can" [...]. It is of course very important to see if there are people around them who can give them support. [...] In this particular case, I knew the girls very well and also the families, so I knew that there was a lot of support there.

The first 'step', it appeared, from the informants' narratives, is for the counsellors to try to prevent an abortion from happening in the first place. As Abdel, Baasim and Father James describe above, this can, for example, be accomplished through various modes of 'positive encouragement', and by ensuring that the baby will be well cared for after delivery. If the baby is born into a caring and loving family, there are few legitimate reasons available for terminating the pregnancy, several informants suggested.

However, if a woman decided to abort the child anyway, informants suggested several ways in which the sin could be dealt with. It is important to remember that God can always forgive a person who acted in a religiously undesirable way, many informants said. "God will forgive everything, everything, everything, there are no things that he will not be able to forgive", the Muslim counsellor, Abdel, explained. Also the Buddhists, Kristina and Indrajalin, said that everyone has the choice to live an ethical life after having acted 'unskilfully' - the Buddhist life signifies a lifelong practice in how to act in an ethically justifiable way-and the Catholic counsellor, Father James, emphasized that the general Christian view is that one should "hate the sin but love the sinner". In other words: the person who committed the sin must always be regarded as a person who can improve in his or her religious conformity. Father James drew attention to Pope Francisco's ordinance about how the Catholic Church should deal with religious confession: "He tells us priests all the time that we must ensure that the confessional box does not turn into a torture-chamber. We are there to help people".

Nevertheless, also evident from the informants' accounts, is that God's forgiveness does not come automatically. Religious counsellors can give advice about how to act, but the woman herself must make the final decision: "The first thing is that one has to truly regret that sin, and the second is to ask God for forgiveness. [...] But the most important thing is that one really regrets what she has done, and [promises] it will never happen again", Baasim said was the case for Muslim women. Beyond engaging in intensified praying, informants also proposed that it is a good idea to 'do good deeds'. The Muslim counsellor, Hasan, said that a person who has taken part in or who has encouraged abortion, for instance, could donate money to socially 
disadvantaged people to mitigate the sin. Father James, in turn, provided more examples of what 'good deeds' could be:

One thing could be to be [increasingly] open for life in the future. Another thing could be to help someone, for example an older person. It is always possible to make suggestions, depending on the individual case. Sometimes people themselves can come up with ideas about what they could do.

The Buddhist counsellor, Kristina, reasoned in similar way as Father James when proposing a solution in line with 'if one takes a life, one has to give one in return': a person who has killed someone could, for example, release fishes or other animals in captivity in order to compensate for the life that was extinguished. It would also be possible for a woman who has had an abortion, or a man who has assisted the woman in doing so, to become a monk or a nun, and thereby devote their lives to ethical reflections, Kristina explains.

Yet again, it is noteworthy that the religious counsellor, Thomas, from the Swedish Church, argued in a way that appeared to be almost opposite to the others. Thomas said that it is understandable that a person who has grown up in a highly devout Christian context can have many thoughts about whether it is truly right to terminate a pregnancy. Some more conservative Christian communities are, for instance, of the opinion that the Swedish abortion law is lax and too liberal, he explained. But, instead of letting his counselling succumb under such Christian dictates, Thomas argued that his task as hospital counsellor is to encourage an adviceseeking woman to think about what she wants:

Yes, so it must be about the woman's own position. Why does she want to have an abortion, for example? The choice must always be hers. Because sometimes one can get pressured from several angles, [someone saying] "Yes, but should you not keep the child and should you not...?", like that. And then it all comes down to: "What do $I$ want in all this? Do I want to become a parent now, am I ready, or can I imagine to [keep it] although I am not ready?" So it is about what one's [personal] starting points are. And this is what will guide the consultation.

Thus, while being aware that some devout people take the Christian principle about 'sacred human life' very seriously, Thomas said that he uses his position as hospital counsellor to encourage women to think and act freely with regard to their decisions on terminating their pregnancies.

\section{Discussion}

This study sought to provide an empirical exploration of the diversity of religious ideas that become manifested in Swedish public healthcare with regard to abortion. We found that most informants saw it as their obligation to provide religious people with abortion advice according to religious norms and principles. They argued that they lacked the freedom within the dictates of their religious ideals to harmonize 
the content of their counselling with Swedish healthcare laws or regulations. Many informants described that it was their responsibility to inform women about their wrongdoing in terminating a pregnancy, and to provide suggestions about how women could mitigate the sin and thereby increase the chances of receiving God's forgiveness. Contrary to what has traditionally been an important ambition in Swedish abortion care-i.e., to reduce women's feeling of shame and guilt with regard to their abortion decisions - the religious counsellors instead argued in favour of imposing liability upon women in order to make them behave "correctly". We also found, however, that some religious counsellors spoke about abortion in a way that was compatible with the Swedish abortion law and public health ambitions on abortion. This was the case regarding the one informant, Thomas, from the Swedish Church. In Thomas' view, he has, as a religious counsellor, the chance to function as a liberating counter-force to devout family members' conservative abortion attitudes, by supporting advice-seeking women to make autonomous reproductive decisions. In sum, our findings show that it cannot be taken for granted that religious counsellors deliver advice that complies with Swedish abortion law and 'womenfriendly' abortion policies; neither can it be assumed that they, in all cases, deliver advice that opposes this agenda.

It is clear that there is a contradiction between the perspectives on abortion: those present in the liberal Swedish discourse and legislation on the one hand, and in many of the religious counsellors' points of view on the other. Crucially, the difference seems to lie in the view of women's entitlement to make decisions about their own bodies and right to make reproductive choices. Women's legal right to abortion in Sweden has been developed alongside ideas about women's emancipation, autonomy, and ability to make independent and rational choices given their current life situation (Elgán 1994; Liljeström 1974; Linders 2004). The Abortion Act reflects a strong belief in women's abilities to make the choices they want; a perspective that is deeply rooted in Swedish feminist and gender equality discourse (Linders 2004; Arousell et al. 2017). While the informant from the Swedish Church supported this perspective, the other religious leaders instead viewed women's decision-making alternatives in relation to the idea that they should succumb under the will of God. Women's choices were not described as 'free' and autonomous as such, but were instead represented as something that must be evaluated according to how well they fit with women's religious obligations. Thus, while the matter of abortion in Swedish discourse and legislation plays out as a relatively private matter upon which the women themselves are to decide, the religious counsellors in our study-except the informant from the Swedish Church - appeared to enforce a system in which women's reproductive decisions also lie in the hands of religious counsellors' interpretations of 'God's words'.

\section{Diversity Promotion in Practice}

Have policy-makers in Sweden tried to confront such manifestations of religious life patterns that seem to conflict with Swedish healthcare laws and public health agenda? At least in the preparatory documents and budget declarations (SST 2017; 
Government Bill 2015/16:1), the level of critical reflection is low. In fact, the tendency is that policy-makers have explicitly argued for both diversity and equality, as if no tension or contradiction exists between the two. There can be several reasons for why the understanding of 'diversity' appears to be superficial. One hypothesis is that when multiculturalist policies become implemented in the governing of welfare systems, it is often made into a matter of representation, non-discrimination and diversity promotion (Wickström 2015). In Sweden, it seems to have been important to ensure that diverse religious communities are represented in healthcare institutions, although little attention has been directed at the political or religious ideas they uphold when patients seek spiritual advice and sympathy. Politicians and policy-makers in welfare institutions in Sweden can easily call for increased religious diversity in healthcare, because the term 'diversity' is so often used in Western countries today, and is associated with strong positive connotations, such that people have stopped reflecting about what it actually might entail (Baehr and Gordon 2018, p. 980). A fear among policy-makers to appear intolerant or narrow-minded regarding diverse life patterns, in case they ask into people's convictions, may have hampered a detailed understanding of various religious ideas. As a consequence, as Gürsel has argued, many non-believers in secular countries often have a difficult time comprehending what it means for people to 'be religious'. One must appreciate, she argues, that, for practitioners of various faiths, it is not possible to arbitrarily enter or exit a religious lifestyle, or to only practice some parts of the religion privately (Gürsel 2013). To succumb under the will of God, as the Egyptian ethnographer Saba Mahmood (2005) has pointed out, may involve daily struggles and sacrifices for managing to stay truthful to one's religious lifestyle. As Ruijs et al. (2013) have observed, and which was also confirmed by our study: religious dictates that challenge the national health agenda cannot easily be abandoned or replaced, because arbitrary interpretations of God's words could risk undermining religious leaders' credibility and authority in the religious community (Ruijs et al. 2013; Agrama 2010).

Another hypothesis about why the actual content of religious counselling in Swedish healthcare has been scarcely discussed, is that policy-makers have truly believed that the services provided by any other faith community are similar to the service provided by the Swedish Church-and therefore function to complement healthcare laws and public health ambitions (see, e.g., SOU 2018:18). They might believe that all various religious counselling is as 'secular' as the counselling provided by the Swedish Church. What policy-makers might have failed to consider, however, is that counsellors within the Swedish Church appear to have had an often non-conflicting relationship with the growth of the Swedish welfare state, by openly supporting the idea that everyone should have equal access to welfare services, regardless of, for instance, gender (Leis-Peters 2009, 2014). Others have argued that there is a general consensus among many counsellors within the Swedish Church that the Church should refrain from choosing sides in political controversies (Pessi et al. 2009). Thus, when the informant, Thomas, from the Swedish Church in our study explained that his role as spiritual counsellor was to help an abortion-seeking woman to make the decision that she wanted, it appears as yet another example of how the Swedish Church takes a silent position on the abortion procedure itself. 
Instead, the individual's existential struggles are at the center of the counsellor's attention. In support of this interpretation are several previous studies that all point in the same direction. People's religious participation (in the Swedish Church) in Sweden has been in decline for many years (Hagevi 2017), and is increasingly being replaced by 'individual spirituality' and unchurched activities (Hamberg 2015). When people in Sweden think of 'religious counselling', it might capture precisely what the informant Thomas referred to: the provision of existential support by a friendly listener in an informal environment, complementing and thereby assisting in the provision of existing welfare services (Leis-Peters 2009) - but without placing any demands upon individuals to succumb under rigid religious doctrine.

\section{The Diversity-Equality Paradox: The Tension Between Two Celebrated Ideals in Swedish Abortion Care}

The findings in this study speak to what social scientist scholars often have referred to as the "diversity-equality paradox" (Baehr and Gordon 2018; Jindra 2014; Emon 2017). The theory can be summarized as follows: the larger the lifestyle diversitywith various groups and individuals oriented towards various life goals, ideals, or convictions - the larger the difficulties in creating equality with regard to specific outcomes in society (Jindra 2014). With regard to the topic of this study, an example of this paradox can be found in the tension between the promotion of religious ideas on abortion on the one hand, and the promotion of liberal ideas about women's reproductive freedom on the other.

As for today, the existence of religious counselling services in Sweden cannot limit women's rights to have an abortion per se. All women in Sweden are equally entitled to the right of having an abortion as prescribed by law, regardless of the ideas held and delivered by religious counsellors. The question is rather about what role Swedish public healthcare institutions should play in the nurturing of certain ideas on abortion, and how influential policy makers would like these ideas to be. Should healthcare institutions serve as a platform for a diversity of ideas on abortion to be manifested, or as an arena for the enforcement of specific types of equality?

A common proposal in the literature on religious counselling in healthcare is that religious leaders can be beneficially included in health promotion programs, but only where their religious advice serves to promote the health goals formulated in public health policies (Padela et al. 2011; Richards 2015; Summerskill and Horton 2015). For instance, Underwood and colleagues have argued that religious leaders in Jordan, if given detailed instructions about what sort of religious ideas to manifest, can assist the Jordanian government's "advocacy for improved reproductive health outcomes" (Underwood et al. 2013, p. e37). Interestingly, although such proposals appear to embrace the ideals of diversity by including religious counselling in the first place, such initiatives are only welcomed if they are assumed to mimic the country's national agenda on promoting liberal ideas on equality. If these proposals would be adhered to in Swedish abortion care, it would mean that the religious counsellors' entitlement to give advice based on their diverse religious convictions would become severely restricted; rather, they would primarily function as 
'spokespersons' for healthcare institutions' already formulated views and ambitions on abortion. Religious counsellors would be expected to adhere to Swedish legislation and policies on abortion when they counsel abortion-seeking women, reflecting an attitude of that women's reproductive freedom is a non-negotiable value that cannot be comprised by any other principle.

While some studies show that religious leaders may agree to perform such healthpromoting tasks (Underwood et al. 2013), Ruijs et al. (2013) found that religious leaders in their Dutch study were unwilling to promote specific health agendas on behalf of the Dutch authorities. This approach has not been extensively discussed in Sweden, neither in the public debate nor in research. It is possible, though, that this alternative would render substantial support from the general public as well as from Swedish politicians: as Borevi points out, the support for multiculturalist policies in Sweden has been noticeable, but only when people have had a sense that the accommodation of religious demands "is not associated with considerable costs and risks" (Borevi 2013, p. 139). However, the religious counsellors in our study expressed significant hesitation in providing advice that violates their religious convictions, which would hamper a solution where only religious advice that complies with Swedish health policies is welcomed.

As also presented in previous research, another alternative would be to go for an option where public healthcare institutions do not actively promote religious ideas in being made manifest in healthcare, but instead allow the religious organizations to attend to these matters themselves - separate from public institutions (Jhutti-Johal 2013). While this would enable religious ideas on abortion to be communicated to members of the religious communities, it would be a decisive message from Swedish welfare institutions that patients visiting Swedish welfare institutions can trust that individuals' reproductive freedom is put first.

\section{Concluding Remarks}

In this study, we have shown that religious ideas on abortion do not always comply with liberal ideas about women's rights to autonomous abortion decisions, as formulated in Swedish health policies. The study has highlighted abortion care as being potentially one of the most obvious cases where the underlying assumption of religious counselling in Swedish healthcare, i.e., that it serves to complement and promote national health policies, becomes challenged. Important tensions between policy ideals appear to emerge when religious ideas encounter principles of equality in Sweden's pluralistic society. We argue that these tensions must be addressed and discussed in order to find an acceptable balance between various perspectives in the provision of abortion care in Sweden. 


\section{Limitations}

It is important to point out that the study does not provide evidence for the actual impact that religious advice may have on women's abortion decisions. Instead, the study sought to provide an understanding of how multiculturalist policies on spiritual counselling open up possibilities for certain ideas to be made manifest. The study's contribution lies in the comparison between the ideas on abortion manifest in Swedish health polices on the one hand, and those in religious counsellors' narratives on the other.

This is an initial exploration of a largely unknown phenomenon, which deserves more attention in future research. For instance, in order to obtain a more comprehensive picture of the impact that religious advice has on women's abortion decisions, we would first need to better understand the processes in which women seek religious advice; what authority they assign to such advice, and how religious advice is argued for and against, and what role family members and others play with regard to the negotiation and incorporation of religious ideas on abortion.

Acknowledgements We would like to thank all of the religious counselors who participated in this study. We also would like to thank the Swedish Research Council for Health, Working Life and Welfare (FORTE), Stiftelsen familjeplaneringsfonden Uppsala, and the Faculty of Medicine at Uppsala University, Sweden, for financial support.

\section{Compliance with Ethical Standards}

Conflict of interest The authors declare that they have no conflict of interest.

Ethical Standards All procedures performed in studies involving human participants were in accordance with the ethical standards of the institutional and/or national research committee and with the $1964 \mathrm{Hel}-$ sinki declaration and its later amendments or comparable ethical standards. The study has been approved by the Regional Ethics Board in Uppsala, Sweden, Dnr: 2013/346.

Informed Consent Informed consent was obtained from all individual participants included in the study.

Open Access This article is distributed under the terms of the Creative Commons Attribution 4.0 International License (http://creativecommons.org/licenses/by/4.0/), which permits unrestricted use, distribution, and reproduction in any medium, provided you give appropriate credit to the original author(s) and the source, provide a link to the Creative Commons license, and indicate if changes were made.

\section{References}

Agrama, H. A. (2010). Ethics, tradition, authority: Toward an anthropology of the fatwa. American Ethnologist, 37(1), 2-18. https://doi.org/10.1111/j.1548-1425.2009.01238.x.

AlRawi, S., Fetters, M. D., Killawi, A., Hammad, A., \& Padela, A. (2012). Traditional healing practices among American Muslims: perceptions of community leaders in southeast Michigan. Journal of Immigrant and Minority Health, 14(3), 489-496. https://doi.org/10.1007/s10903-011-9495-0.

Arousell, J., Carlbom, A., Johnsdotter, S., Larsson, E., \& Essén, B. (2017). Unintended consequences of gender equality promotion in Swedish contraceptive counseling: A discourse analysis. Qualitative Health Research, 27(10), 1518-1528. https://doi.org/10.1177/1049732317697099. 
Baehr, W., \& Gordon, D. (2018). Paradoxes of diversity. In W. Outwaite \& S. P. Turner (Eds.), The SAGE handbook of political sociology (pp. 977-998). London: SAGE Publications Ltd.

Bendixsen, S., Bringslid, M., \& Vike, H. (2018). Introduction: Egalitarianism in a Scandinavian context. In S. Bendixsen, M. Bringslid, \& H. Vike (Eds.), Egalitarianism in Scandinavia. Historical and comparative perspectives (pp. 1-45). Cham: Palgrave MacMillan.

Borevi, K. (2013). The political dynamics of multiculturalism in Sweden. In R. Taras (Ed.), Challenging multiculturalism: european models of diversity (pp. 138-160). Edinburgh: Edinburgh University Press.

Borevi, K. (2014). Multiculturalism and welfare state integration: Swedish model path dependency. Identities-Global Studies in Culture and Power, 21(6), 708-723. https://doi.org/10.1080/10702 89X.2013.868351.

Carlbom, A. (2003) The imagined versus the real other. Multiculturalism and the representation of muslims in Sweden. Lund: Department of Sociology, Lund University (diss).

Elgán, E. (1994). Genus och politik. En jämförelse mellan svensk och fransk abort- och preventivmedelspolitik från sekelskiftet till andra världskriget [Gender and politics. A comparision between Swedish and French abortion and contraceptive politics from the turn of the century to the Second World War]. Uppsala: Department of History, Uppsala University (diss).

Emon, A. M. (2017). The paradox of equality and the politics of difference: Gender equality, Islamic Law and the modern Muslim state. In Z. Mir-Hosseini, K. Vogt, L. Larsen, \& C. Moe (Eds.), Gender and equality in Muslim family law: Justice and ethics in the Islamic legal tradition. London: IB Tauris. https://doi.org/10.2139/ssrn.1758966.

Government Bill 1974:70. Kunglig Majestäts proposition med förslag till abortlag. [Your Majesty's Proposition with Suggestion for an Abortion Act]. Stockholm.

Government Bill 1975:26. Om riktlinjer för invandrar och minoritetspolitiken m.m. [On guiding principles for the immigrant and minority policy, etc.]. Stockholm.

Government Bill 1997/98:16. Sverige, framtiden och mångfalden - från invandrarpolitik till integrationspolitik. [Sweden, the Future, and the Diversity-from immigrant politics to integration politics]. Stockholm.

Government Bill 2015/16:1. Budgetpropositionen för 2016. Förslag till statens budget för 2016, finansplan och skattefrågor [The Budget Proposition for 2016. Proposals for the state's budget for 2016, plan of finance, and tax questions]. Stockholm: Ministry of Finance.

Gürsel, E. D. (2013). The distinction between the freedom of religion and the right to manifest religion. Social \& Legal Studies, 22(3), 377-393. https://doi.org/10.1177/0964663913477679.

Hagevi, M. (2017). Religious change over the generations in an extremely secular society: The case of Sweden. Review of Religious Research, 59(4), 499-518. https://doi.org/10.1007/s13644-017-0294-5.

Hamberg, E. M. (2015). Religious monopolies, religious pluralism, and secularization: The relationship between religious pluralism and religious participation in Sweden. Interdiciplinary Journal of Research on Religion, 11(6), 3-15.

Jhutti-Johal, J. (2013). Understanding and coping with diversity in healthcare. Health Care Analysis, 21, 259-270. https://doi.org/10.1007/s10728-013-0249-0.

Jindra, M. (2014). The dilemma of equality and diversity. Current Anthropology, 55(3), 316-334. https:// doi.org/10.1086/676457.

Leis-Peters, A. (2009). Majority Church and welfare in Sweden: Some reflections on results from two Swedish research projects: A response to Beate Hofmann. Christian Bioethics, 15(2), 147-153. https://doi.org/10.1093/cb/cbp009.

Leis-Peters, A. (2014). Hidden by civil society and religion? Diaconal institutions as welfare providers in the growing Swedish welfare state. Journal of Church and State, 56(1), 105-127. https://doi. org/10.1093/jcs/cst134.

Liljeström, R. (1974). A study of abortion in Sweden. A contribution to the United Nations world population conference. Stockholm: The Royal Ministry of Foregin Affairs.

Lincoln, Y. S., \& Guba, E. G. (1985). Naturalistic inquiry. Beverly Hills, CA: Sage.

Linders, A. (2004). Victory and beyond: A historical comparative analysis of the outcomes of the abortion movements in Sweden and the United States. Sociological Forum, 19(3), 371-404. https://doi. org/10.1023/B:SOFO.0000042554.66359.1d.

Mahmood, S. (2005). Politics of piety. The Islamic revival and the feminist subject. Princeton, NJ: Princeton University Press.

Moberg, J., \& Ståle, G. (2014). Helig hälsa: helandemetoder i det mångreligiösa Sverige. [Sacred Health: Curative Methods in the Multireligious Sweden]. Stockholm: Dialogos. 
Ouis, P., Adamson, G., \& Carlbom, A. (2013). Is multiculturalism good for children? The rights of the child and multiculturalist policies in Sweden. ID: International Dialogue, A Multidisciplinary Journal of World Affairs (3), 77-93. ISSN 2155-160X.

Padela, A., Killawi, A., Heisler, M., Demonner, S., \& Fetters, M. D. (2011). The role of Imams in American Muslim health: Perspectives of Muslim community leaders in Southeast Michigan. Journal of Religion and Health, 50(2), 359-373. https://doi.org/10.1007/s10943-010-9428-6.

Pessi, A. B., Angell, O. H., \& Pettersson, P. (2009). Nordic majority churches as agents in the welfare state: Critical voices and/or complementary Providers. Temenos, 45(2), 207-234.

Polit, D. F., \& Beck, C. T. (2010). Generalization in quantitative and qualitative research: Myths and strategies. International Journal of Nursing Studies, 47(11), 1451-1458. https://doi.org/10.1016/j. ijnurstu.2010.06.004.

Richards, E. (2015). The catholic church and reproductive health and rights in Timor-Leste: Contestation, negotiation and cooperation. Culture, Health \& Sexuality, 17(3), 343-358. https://doi. org/10.1080/13691058.2014.966255.

Ruijs, W., Hautvast, J. L., Kerrar, S., van der Velden, K., \& Hulscher, M. E. (2013). The role of religious leaders in promoting acceptance of vaccination within a majority group: A qualitative study. $B M C$ Public Health, 13, 511.

SOU 2005:90. Abort i Sverige [Abortion in Sweden]. Stockholm: The Swedish Government.

SOU 2018:18. Statens stöd till trossamfund $i$ ett mångreligiöst Sverige. Betänkande av Utredningen om översyn av statens stöd till trossamfund [The State's Support to Faith Communities in a Multireligious Sweden. Report from the investigation about the review of the state's support to faith communities]. Stockholm: The Swedish Government.

SST (2017). Budget Request 2017. Swedish Agency for Support to Faith Communities (SST). Retrieved from: http://myndighetensst.se/download/18.414c21df152e0b4bbb569d21/1455699749956/Budge tunderlag+2017+slutversion.pdf. 10 September 2018.

SST. (2019). Statistik. Swedish Agency for Support to Faith Communities (SST). Retrieved from: https:// www.myndighetensst.se/andligvard/statistik.html. 24 May 2019.

Stebbins, R. (2001). Exploratory research in the social sciences (Vol. 48)., Sage University Papers Series on Qualitative Research Methods Thousand Oaks, CA: Sage.

Summerskill, W., \& Horton, R. (2015). Faith-based delivery of science-based care. Lancet, 386(10005), 1709-1710. https://doi.org/10.1016/S0140-6736(15)61104-7.

Thorne, S., Armstrong, E., Harris, S. R., Hislop, G. T., Kim-Sing, C., Oglov, V., et al. (2009). Patient real-time and 12-month retrospective perceptions of difficult communications in the cancer diagnostic period. Qualitative Health Research, 19(10), 1383-1394. https://doi.org/10.1177/1049732309 348382.

Underwood, C., Kamhawi, S., \& Nofal, A. (2013). Religious leaders gain ground in the Jordanian familyplanning movement. International Journal of Gynecology \& Obstetrics, 123(Suppl 1), e33-e37. https://doi.org/10.1016/j.ijgo.2013.07.006.

Wickström, M. (2015). Comparative and transnational perspectives on the introduction of multiculturalism in post-war Sweden. Scandinavian Journal of History, 40(4), 512-534. https://doi. org/10.1080/03468755.2015.1060897.

Publisher's Note Springer Nature remains neutral with regard to jurisdictional claims in published maps and institutional affiliations. 